\section{Kidney \\ Blood Pressure Research}

\title{
Interleukin 17A and Toll-like Receptor 4 in Patients with Arterial Hypertension
}

\author{
Tihana Simundic Bojan Jelakovic Andrea Dzumhur Tajana Turk \\ Ines Sahinovic Blazenka Dobrosevic Boris Takac Jerko Barbic \\ University Hospital Center Osijek and Department of Pathophysiology, Faculty of Medicine, \\ University of Osijek, Croatia
}

\section{Key Words}

Arterial hypertension • Toll-like receptor 4 - Interleukin 17A • Innate immunity • Adaptive immunity

\begin{abstract}
Background/Aims: Immune responses are involved in arterial hypertension. An observational cross-sectional case control study was conducted to estimate the association between Toll-like receptor 4 (TLR4) expression and interleukin (IL)-17A serum levels in patients with controlled and non-controlled hypertension. Methods: We have enrolled 105 non-complicated otherwise healthy hypertensive patients: 53 with well-controlled blood pressure and 52 noncontrolled. TLR4 peripheral monocytes expression and serum IL-17A levels were determined by flow cytometry and ELISA, respectively. Results: Non-controlled patients exhibited higher TLR4 expression than well-controlled ( 25.60 vs. $21.99, P=0.011$ ). TLR4 expression was lower in well-controlled patients who were prescribed beta blockers (18.9 vs. $22.6, P=0.005)$ and IL-17A concentration was higher in patients using diuretics in either group $(1.41 \mathrm{vs} .2 .01 \mathrm{pg} /$ $\mathrm{ml}, P<0.001$; well-controlled 1.3 vs. $1.8 \mathrm{pg} / \mathrm{ml}, P=0.023$; non-controlled 1.6 vs. $2.3 \mathrm{pg} / \mathrm{ml}$, $P=0.001$ ). Correlation between IL-17A concentration and hypertension duration was observed in non-controlled patients (Spearman correlation coefficient . $\rho=0.566, P<0.001$ ) whereas in well-controlled patients a correlation was found between hypertension duration and TLR4 expression ( $\rho=0.322, P=0.020$ ). Conclusions: Arterial hypertension stimulates the immune response regardless of blood pressure regulation status. Prolonged hypertension influences peripheral monocyte TLR4 expression and IL-17A serum levels. Anti-hypertensive drugs have different immunomodulatory effects: diuretics are associated with higher IL-17A concentration and beta-blockers with lower TLR4 expression.
\end{abstract}




\section{Kidney Blood Pressure Research}

\section{Introduction}

Essential hypertension is thought to originate from interaction between genetic and environmental factors. The immune system and its aberrant activation are thought to play a role in hypertension It was also found that certain chronic inflammatory diseases such as psoriasis or rheumatoid arthritis are often associated with arterial hypertension [1, 2]. Although the first studies linking hypertension and immunity were conducted several decades ago $[3,4]$, it is only recently that attention has been directed to distinct components of innate and adaptive immune responses [5-8]. Toll like receptors (TLRs), one of most important pathogen recognition receptor of innate immunity can be also activated by tissue injury antigens (danger associated with molecular patterns; DAMPs) [9, 10]. Upon activation and the induction of NF- $\kappa \mathrm{B}$ transcription factors, they lead to the expression of pro-inflammatory cytokines, chemokines, and activation of adaptive immunity [11-14]. It is assumed that DAMP-mediated TLR activation itself causes inflammation and hypertension [15]. Notably, to date approximately a dozen TLRs have been identified only in mammals, and the most extensive research linking arterial hypertension and TLRs has been performed on TLR4 [15-18]. TLR4 is also thought to play an important role in acute renal failure and diabetic nephropathy $[19,20]$. However, these studies have all utilized animal models or cell culture; and only a few clinical studies have investigated the correlation between TLR and human hypertension. In particular, Marketou et al. have reported a significant increase in TLR4 gene expression in peripheral monocytes in non-diabetic patients with hypertension and a decrease in TLR2 and TLR4 gene expression following intensive bloodpressure therapy [21]. In addition, some of the genetic variants of TLR2 are thought to exert a protective role against arterial hypertension and acute myocardial infarction [22]. Further studies on the clinical relevance of TLRs and the role of innate immunity in human hypertension are required.

Unlike the innate immune response, the adaptive response is highly specific and is mediated by T and B lymphocytes. Recently, a newly identified class of T helper lymphocytes, Th17 lymphocytes, has attracted considerable attention. Although interleukin (IL)-17 can be produced by some other cell types, Th17 lymphocytes represent the primary source of this cytokine [23-26]. There are six types of IL-17 (A-F), but IL-17A is currently considered to be the most clinically relevant, being associated with various chronic diseases including cardiovascular ones [27-31]. One of the most important studies relating hypertension and Th17 response showed that angiotensin II infusion in an animal model increased the level of circulating Th17 lymphocytes as well as the production of IL-17A by Th17 cells and its accumulation in the circulation [24]. This study also demonstrated that IL-17A is required for the maintenance of angiotensin II-induced hypertension and further illustrated increased serum concentrations of IL-17A in patients with diabetes mellitus and hypertension compared to those with diabetes alone [24]. Subsequently, interleukin 17 was discovered to directly increase blood pressure by decreasing endothelial nitric oxide production [32]. In addition, IL-17A level have recently been reported to be higher in non-diabetic patients with hypertension and asymptomatic organ damage compared to those without such damage [33], as well as in a patient population exhibiting prehypertension [34]. It was speculated that IL 17 might have a protective role with respect to cardiovascular diseases [35-37].

The sympathetic overactivity can activate immune cells $[38,39]$. On the other hand, the parasympathetic arm can suppress immune cells [38]. Recently, it has been demonstrated that spontaneously hypertensive rats exhibit an up-regulation of TLR4 within the paraventricular nucleus and that TLR4 inhibition therein attenuates blood pressure [40]. Several other studies have reported connections between the nervous system, inflammation, and hypertension [41-44].

Considering that scarcity of the studies investigating the correlation between human hypertension and immunity are available, our aim was to analyze expression of TLR4 and IL-17A in controlled and non-controlled patients with uncomplicated hypertension, and to determine whether they were influenced by antihypertensive drugs and duration of hypertension. 


\section{Kidney Blood Pressure Research}

\author{
Patients and Methods
}

Kidney Blood Press Res 2017;42:99-108

\begin{tabular}{l|l}
\hline DOI: $10.1159 / 000471900$ & (C) 2017 The Author(s). Published by S. Karger AG, Basel
\end{tabular}

Published onlıne: March 31, 2017

www.karger.com/kb

Simundic et al.: Hypertension and Immunity

Study population

A total of 105 patients, age 20-60, with essential hypertension were included in the study. This study was conducted at Department of Nephrology, Clinical Hospital Center Osijek, Croatia, between May 2012 and November 2015. Patients were recruited from consecutive 105 essential hypertensive patients who met all of the criteria. All patients provided written informed consent, and the study was approved by the Ethical Committee of the Clinical Hospital Center Osijek. Patients were divided into two groups, consisting of 53 patients with controlled arterial hypertension and 52 with non-controlled hypertension. Most of the patients in both groups were taking multiple antihypertensive therapy. Patients taking Henles loop diuretics or spironolactone were not included in the study, but only those taking thiazide diuretics. The exclusion criteria were: secondary hypertension diagnosed using standardized protocols; statin, non-steroid antiinflammatory drugs (NSAID), or any kind of immunosuppressive therapy; chronic kidney disease (eGFR -CKD-Epi $<60 \mathrm{ml} / \mathrm{min} / 1-73 \mathrm{~m} 2$ ) or any other chronic inflammatory disease; diabetes mellitus, malignancy, pregnancy or lactating (if female), previous cardiovascular and cerebrovascular events, or any sign of acute infection or pathological urine finding. Complete medical history was obtained from the patients and they received a complete clinical examination as well as standard echocardiography and routine laboratory analysis. The data on the duration of hypertensive condition was obtained via patient report and medical records. Blood pressure was measured with an Omron M6 Comfort device on both hands three times according to the $2013 \mathrm{ESH} / \mathrm{ESC}$ guidelines and hypertension was defined as blood pressure $\geq 140 / 90 \mathrm{mmHg}$ [45]. Blood samples used to determine IL-17A concentration were collected into a vacutainer without anticoagulant and were centrifuged at $3000 \mathrm{~g}$ for $10 \mathrm{~min}$. The free flow cytometry used to determine the TLR4 expression was performed the same day and the samples used to determine IL-17A were preserved at $-20^{\circ} \mathrm{C}$ until assayed.

\section{Measurement of IL-17A concentration and TLR4 expression}

Serum IL-17A concentrations were measured by enzyme-linked immunosorbent assay (ELISA) protocol (eBioscience, human IL-17, platinum ELISA, cat.no.2017) following manufacturer instruction. The room temperature during the ELISA analysis was $24^{\circ} \mathrm{C}$. The results were obtained using diagnostic MRX, a Dynatech Laboratories instrument. The sample for free flow cytometry consisted of blood taken with an anticoagulant (EDTA). Monoclonal antibodies produced by eBioscience and BD Biosciences were used. The fluorescence intensity of the membrane markers was measured using FACSCALibur flow cytometer. The results were analyzed using the CELL Quest program. The graph showing the flow cytometry analysis (dot plot diagram) included a gate set up for monocyte populations. The analysis demonstrated that the involved monocytes, according to their positivity, were CD14+, in the range from $95 \%$ up to $100 \%$. The results were expressed as a percentage (the part of monocyctes CD14+ on TLR4), as well as by the mean fluorescence intensity (MFI). The instrument accuracy was tested using standard CALIBRITE 3 optic beads (BD Biosciences) and a negative isotype control was used.

\section{Statistical analysis}

The category data were presented in absolute and relative frequencies. The numerical data were described using median and interquartile ranges. The differences of category variables were tested with a $\chi^{2}$ test and if necessary with a Fisher accuracy test. A Kolmogor-Smirnov test was used to evaluate the normality distribution of numeric variables. The differences in numerical variables between two independent groups were tested using a Mann Whitney $\mathrm{U}$ test. The correlation grading was expressed with the Spearman coefficient Rho (all $P$ values were two-sided). The level of significance was set with $\alpha=0.05$. The statistical program SPSS (version 16.0, SPSS Inc.) was used for the statistical analysis.

\section{Results}

The study included demographic and laboratory findings of the whole group, which are presented in Table 1 . Table 2 shows the prescribed antihypertensive therapy taken by the patients at the time when they were included in the study.

All participants were from 20-60 years old. Systolic and diastolic blood pressure val- 


\section{Kidney Blood Pressure Research}

ues were significantly higher in the non-controlled hypertensive group $(P<0.001)$. Laboratory values of complete blood and urine checks were within normal ranges in all participants. Total cholesterol was higher in the non-controlled hypertensive group, whereas high density lipoprotein values were higher in the controlled hypertensive group. The duration of hypertension, body mass index, and number of smokers were notsignificantly different between groups. Notably, the group of non-controlled hypertensive patients had significantly higher TLR4 expression: 25,60 (IQR 20,6 - 30,1) vs. $21,99(18,9-25,01)$, Mann Whitney U test, $\mathrm{P}=0,011$ (Figure 1). We found no significant difference in IL-17A concentration between the two patients' group. Furthermore, we found no correlation between IL17 level and TLR 4 expression. As shown in Figure 2, patients who were treated with beta blockers
Table 1 Demographic and laboratory data of enrolled patients

\begin{tabular}{|c|c|c|c|}
\hline Variable & $\begin{array}{l}\text { Non-controlled } \\
\text { Hypertensives } \\
(\mathrm{N}=52) \\
\end{array}$ & $\begin{array}{c}\text { Controlled } \\
\text { Hypertensives } \\
(\mathrm{N}=53) \\
\end{array}$ & $\begin{array}{c}P \\
\text { Value* }\end{array}$ \\
\hline Male [N(\%)] & $26(50)$ & $16(30.2)$ & \multirow{2}{*}{$0.047^{\dagger}$} \\
\hline Female $[\mathrm{N}(\%)]$ & $26(50)$ & 37 (69.8) & \\
\hline Age, [years] & $51(42-58.8)$ & $45(40.5-51)$ & 0.010 \\
\hline Smokers [N(\%)] & $11(21.2)$ & $15(28.3)$ & $0.499^{\dagger}$ \\
\hline $\begin{array}{l}\text { Body mass index, } \mathrm{kg} / \mathrm{m}^{2} \\
\text { [Median, IQR } \neq]\end{array}$ & $29(24.8-33.6)$ & $28.9(25.4-31.6)$ & 0.544 \\
\hline $\begin{array}{l}\text { Fasting glucose, } \mathrm{mmol} / \mathrm{L} \\
\text { [Median, IQR] }\end{array}$ & $5.1(4.8-5.7)$ & $5.1(4.8-5.5)$ & 0.560 \\
\hline Creatinine, umol/L Median, IQR] & $77(66-81.5)$ & $66(60-74)$ & 0.003 \\
\hline eGFR ml/min/1.73 m² [Median, IQR] & $96(86.5-106.5)$ & $103(94-111)$ & 0.016 \\
\hline $\begin{array}{l}\text { Total cholesterol, } \mathrm{mmol} / \mathrm{L} \\
\text { [Median, IQR] }\end{array}$ & $5.8(5-6.6)$ & $5.2(4.52-5.92)$ & 0.006 \\
\hline $\begin{array}{l}\text { Triglycerides, mmol/L } \\
\text { [Median, IQR] }\end{array}$ & $1.7(1.3-2.5)$ & $1.3(0.95-2.09)$ & 0.065 \\
\hline $\begin{array}{l}\text { LDL (low-density lipoprotein) } \\
\text { cholesterol, mmol/L } \\
\text { [Median, IQR] }\end{array}$ & $3.8(3.0-4.34)$ & $3.5(2.86-3.9)$ & 0.713 \\
\hline $\begin{array}{l}\text { HDL (high-density lipoprotein) } \\
\text { cholesterol, mmol/L } \\
\text { [Median, IQR] }\end{array}$ & $1.29(1.08-1.44)$ & $1.3(1.1-1.4)$ & 0.038 \\
\hline $\begin{array}{l}\text { Systolic blood pressure, } \mathrm{mm} \mathrm{Hg} \\
\text { [Median, IQR] }\end{array}$ & $155.5(148-165)$ & $125(120-131,5)$ & $<0.001$ \\
\hline $\begin{array}{l}\text { Diastolic blood pressure, } \mathrm{mm} \mathrm{Hg} \\
\text { [Median, IQR] }\end{array}$ & $100(91-109.7)$ & $84(79-90)$ & $<0.001$ \\
\hline $\begin{array}{l}\text { Duration of hypertension, years } \\
\text { [Median, IQR] }\end{array}$ & $1(0.16-7)$ & $2(1-5)$ & 0.163 \\
\hline
\end{tabular}

Table 2. Prescribed antihypertensive therapy taken by the patients at the time when they were included in the study

\begin{tabular}{lcccc}
\hline \multirow{2}{*}{ Therapy } & \multicolumn{3}{c}{ Number (\%) of participants } & \multirow{2}{*}{$P^{*}$} \\
\cline { 2 - 4 } & $\begin{array}{c}\text { Regulated } \\
\text { AH }\end{array}$ & $\begin{array}{c}\text { Unregulated } \\
\text { Non- } \\
\text { controlled AH }\end{array}$ & Total & \\
\hline Inhibitors of ACE & $38(71.7)$ & $29(55.8)$ & $67(63.8)$ & 0.107 \\
Thiazide Diuretics & $20(37.7)$ & $12(23.1)$ & $32(30.5)$ & 0.138 \\
Calcium chanel & $29(54.7)$ & $29(55.8)$ & $58(55.2)$ & $>0.950$ \\
blockers & & & & \\
Beta blockers & $14(26.4)$ & $7(13.5)$ & $21(20)$ & 0.143 \\
ATR1 blockers & $4(7.5)$ & $6(11.5)$ & $10(9.5)$ & 0.526 \\
Central anti-adrenergic & $3(5.7)$ & $7(13.5)$ & $10(9.5)$ & 0.201 \\
(moxonidine) & & & & \\
\hline *Fisher's Exact test & \multicolumn{4}{l}{} \\
\hline
\end{tabular}

had a significantly lower level of TL4 expression $(P=0.001)$. In the group of patients with controlled hypertension, the expression of TLR4 was significantly lower in those who were on beta blockers compared to those who were not: 18.9 (IQR 18.1-20.1) vs. 22.6 (IQR 20.2$25.9),(P=0.005)$. A difference in TL4 expression was also noted in the group of patients with non-controlled hypertension between those who took beta blockers and those who did not: 20.5 (IQR 18-27.4) in comparison to 25.9 (IQR 21.1-30.5), but this was not significant. Serum concentrations of IL-17A were significantly higher in those treated with diuretics: whole group $1.41 \mathrm{pg} / \mathrm{ml}$ (IQR 0.93-1.9 pg/ml) vs. $2.01 \mathrm{pg} / \mathrm{ml}$ (IQR 1.5-2.4 pg/ml), Mann Whitney U test $P<0.001$ (Fig. 3); controlled, and $1.3 \mathrm{pg} / \mathrm{ml}$ (IQR $0.8-1.8 \mathrm{pg} / \mathrm{ml}$ ) vs. $1.8 \mathrm{pg} /$ $\mathrm{ml}$ (IQR $1.4-2.3 \mathrm{pg} / \mathrm{ml}$ ), Mann Whitney U test $P=0.023$; non-controlled patients, $1.6 \mathrm{pg} / \mathrm{ml}$ (IQR $1.2-2 \mathrm{pg} / \mathrm{ml}$ ) vs. $2.3 \mathrm{pg} / \mathrm{ml}(1.9-2.6 \mathrm{pg} / \mathrm{ml})$, Mann Whitney U test $P=0.001$. None of the participants included in the study received spironolactone as a diuretic. No differences in TLR4 expression or IL-17A serum level were observed considering other antihypertensive drugs classes. In the group of the patients with non-controlled hypertension, there was a significant correlation between the level of IL-17A and hypertension duration (Spearman 


\section{Kidney \\ Blood Pressure Research}

Coeff. Corr. $\rho=0.566, P<0.001$, Figure 4.) and in the group with controlled hypertension, there was a significant correlation between TLR4 expression and hypertension duration (Spearman Coeff. Corr. $\rho=0.322, P=0.020$, Figure 5. ).

\section{Discussion}

Our study has shown that patients with non-controlled hypertension showed higher TLR4 expression on their peripheral monocytes in comparison to those with controlled hypertension. This might indicate that poor blood pressure control is related to the activated innate immunity which could contribute to tissue and organ damage and thus influence disease progression and prognosis. Importantly, we demonstrate for the first time that the duration of hypertension might have an immune-modulating effect. It would appear that although controlled, hypertension can still be a trigger for immune stimulation, as was demonstrated by the close correlation between the duration of controlled hypertension and higher TLR4 expression. On the other hand, the duration of non-controlled hypertension was closely linked to a higher level of IL-17A in serum which is in line with other studies $[33,34]$ that found association between IL-17A and blood pressure values. Indeed, higher levels of IL-17A might be related to activated innate immunity, could be influenced by the used class of antihypertensive drugs or, as suggested by some authors might have protective role.

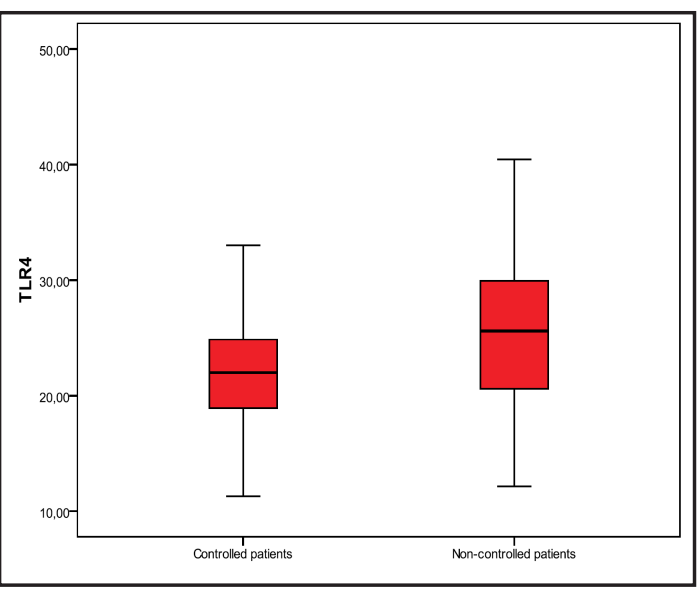

Fig. 1. Difference in TLR4 expression between controlled and non-controlled patients: non-controlled patients exhibited higher TLR4 expression than controlled (25.60 vs. 21.99, $P=0.011$ ).

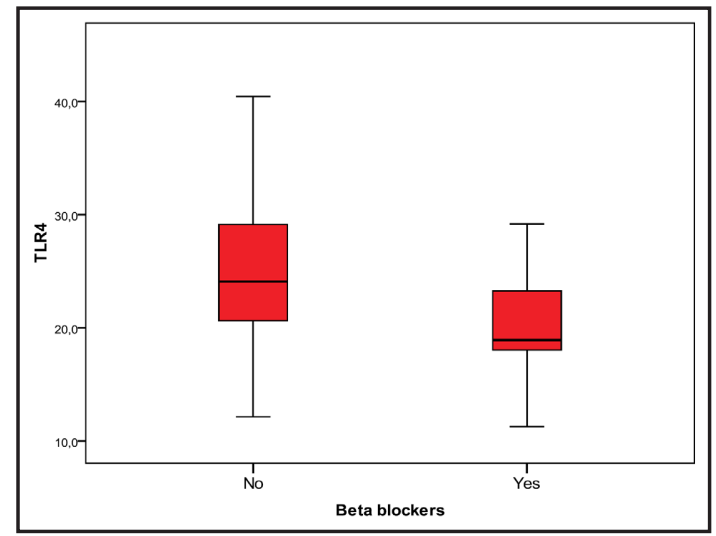

Fig. 2. TLR4 expression was lower in controlled patients who were prescribed beta blockers (18.9 vs. 22.6, $P=0.005$ ). Hypertension is associated with increased inflammatory markers such as C-reactive protein, cytokines, chemokines, and adhesion molecules [46-48].

TLR activation via DAMPs is believed to link inflammation to hypertension, TLR4 being mostly in focus $[15-18,49]$. Anti-TLR4 antibody treatment reduces blood pressure and inflammation in spontaneously hypertensive rats [16], and significantly higher TLR4 mRNA levels are found in peripheral monocytes in non-diabetic hypertensive patients [21]. Our results showing higher TLR4 expression in patients with non-controlled vs. controlled hypertension are consistent with these studies. In addition, the correlation between the duration of controlled hypertension and peripheral monocytes TLR4 expression suggests that hypertension, even when controlled might be a permanent, hidden cause of unspecific inflammatory response. When innate immune system response is strong and of sufficient duration, it might activate the specific immune response, in particular involving Th17 class of T-helper lymphocytes, the primary source of IL-17 [25, 26]. IL-17, via NF-kB, stimulates pro-inflammatory genes, enhancing the production of various proinflammatory cytokines and chemokines [50,51]. IL-17A in particular plays important roles in various chronic inflammation conditions, autoimmune diseases [1, 29-31], and in acute coronary syndrome 


\section{Kidney \\ Blood Pressure Research}

[2]. It has been shown that this cytokine maintains hypertension and contributes to vascular dysfunction [24]. Higher IL-17A levels are associated with hypertension in patients with diabetes [24] and IL-17 has been closely linked with endothelial dysfunction, hypertension, end stage organ damage, and atherosclerotic conditions [32, $33,48]$ exhibiting both pro-inflammatory and protective effect [37]. It was recently reported that shortage of IL-17/IL-23 leads to increased albuminuria and kidney damage in patients with hypertension [52].

Our results suggest that the correlation between non-controlled, prolonged hypertension and IL-17A levels might mean that prolonged non-controlled arterial hypertension and its consequences are identified by immune system as a strong threat, triggering the whole immune cascade until achieving a certain level of immunity. The lack of significant difference in the IL-17A levels between the studied groups suggests that the activation of specific immunity might be triggered not only by the hypertension itself, but that the duration of non-controlled hypertension might be considered as an important factor in the activation of specific immunity .

Serum concentrations of IL-17A in our study were low in all patients, which is similar to some other studies [33]. Besides that, it is known that cytokines have short serum half-life and very often undetectable baseline levels. Additional challenges might be caused by analytical, methodological, and study design-related variables.

The choice of anti-hypertension therapy could also modulate immune system and its response. The data regarding beta blocker intake and peripheral monocyte TLR4 expression and that of diuretic use and IL17A concentration with respect to human

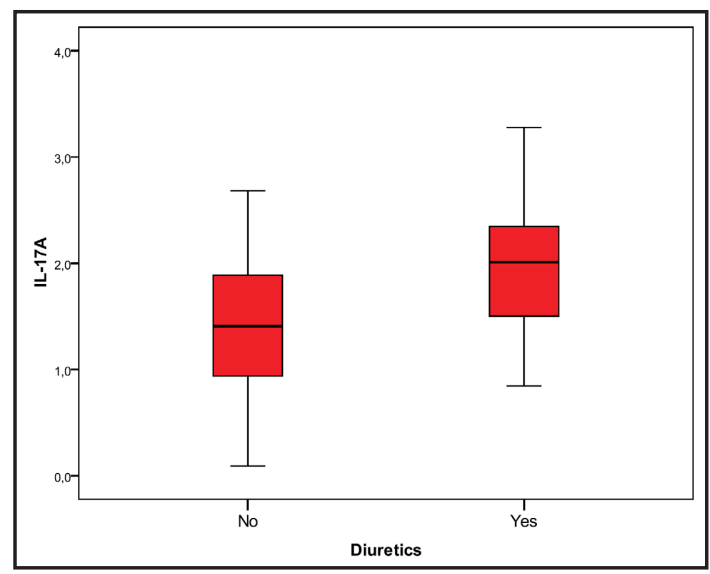

Fig. 3. Serum concentrations of IL-17A were significantly higher in those treated with diuretics: whole group $1.41 \mathrm{pg} / \mathrm{ml}$ vs. $2.01 \mathrm{pg} / \mathrm{ml}$, Mann Whitney U test $P<0.001$, (controlled 1.3 vs. $1.8 \mathrm{pg} / \mathrm{ml}, P=0.023$; non-controlled 1.6 vs. $2.3 \mathrm{pg} / \mathrm{ml}, P=0.001$ ). None of the participants included in the study received spironolactone as a diuretic.

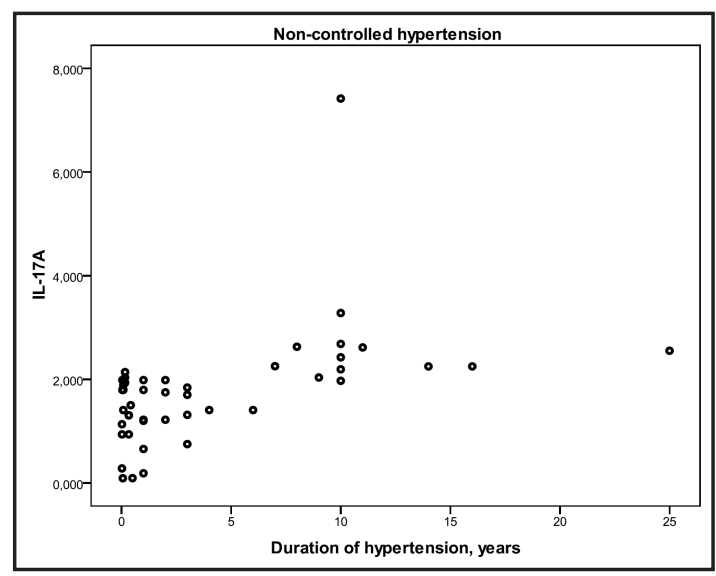

Fig. 4. Correlation between IL-17A concentration and hypertension duration was observed in the group of patients with non-controlled hypertension (Spearman Coeff. Corr. $\rho=0.566, P<0.001$ ). arterial hypertension have not, to the best of our knowledge, been previously reported in the literature. The patients who were treated with beta blockers exhibited lower TLR4 expression that was more evident in the group with controlled hypertension, while patients taking diuretics had a higher concentration of serum IL-17A regardless of how well their hypertension was controlled.

The role of beta adrenergic receptor in inflammation was described in several studies $[53,54]$, and it was shown that beta receptor blockade is associated with lower levels of $\mathrm{C}$ reactive protein [55]. Specifically, lymph nodes and spleen are richly innervated with sympathetic nerves that terminate in $\mathrm{T}$ cell rich areas. Once activated, these immune cells migrate to the CNS causing a positive feedback that results in enhanced sympathetic activity and a pro-inflammatory effect in the peripheral areas [41, 42]. In addition angiotensin II 


\section{Kidney Blood Pressure Research}

Kidney Blood Press Res 2017;42:99-108

\begin{tabular}{|l|l|l|l|l}
\hline DOI: $10.1159 / 000471900$ & C 2017 The Author(s). Published by S. Karger AG, Basel
\end{tabular}

Published onlıne: March 31, 2017 www.karger.com/kbr

Simundic et al.: Hypertension and Immunity

stimulates the immune response in the spleen through its enhanced CNS delivery [56]. On the other hand, TLR4 inhibition within the paraventricular nucleus was shown to lower blood pressure and reduce the inflammatory response [40].

Our results also suggested that the immune response changed in the patients who were prescribed thiazide diuretics to manage their hypertension, as evidenced by increased serum IL-17A associated with diuretic use, especially in patients with non-controlled hypertension. This was evident regardless of the other antihypertensive therapy taken along with thiazide diuretic. It is known that these diuretics cause sodium depletion that can lead to compensatory activation

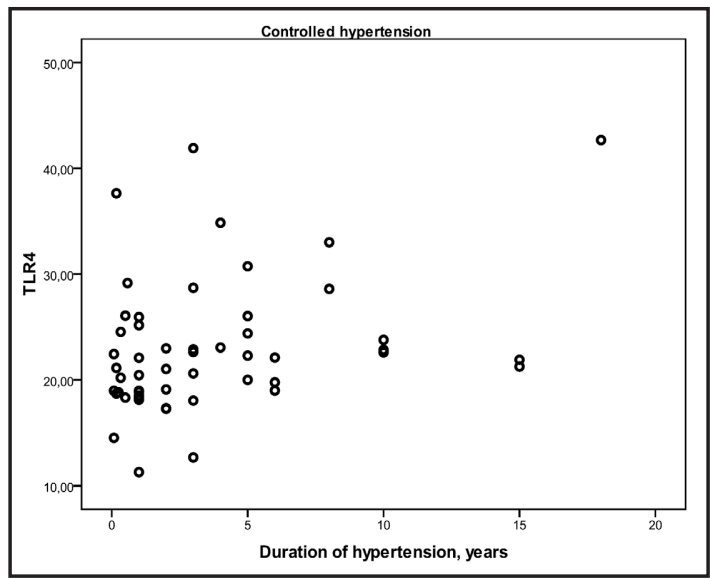

Fig. 5. Correlation between TLR4 expression and hypertension duration was observed in the group of patients with controlled hypertension (Spearman Coeff. Corr. $\rho=0.322, P=0.020$ ). of the RAAS as well as the SNS; these counter-regulatory mechanisms promote vasoconstriction and sodium retention, which can reduce the effects of the diuretics [57]. Activated RAAS, primarily angiotensin II, has various proinflammatory effects including Th 17 differentiation [58] and promotion of IL 17 production [24]. There are also extensive data on the negative metabolic effects of diuretics; therefore, the activation of the immune response by diuretics when used in hypertension therapy might also occur via an unspecified metabolic mechanism. Therefore, the relevance and specificity of the observed IL-17A increase should be further investigated. No significant differences were observed in TLR4 expression or IL-17A levels in the patients who received renin-angiotensin-aldosterone blockers (ACE inhibitors and AT1 receptor blockers) as part of their hypertension therapy. These drugs are known to have anti-inflammatory effects $[59,60]$. Nevertheless, similar data exist regarding some other anti-hypertensive drugs exhibiting theirs anti-inflammatory effects [55]. Blockade of angiotensin II type 1 receptors significantly decrease the levels of VCAM-1 and TNF $\alpha$, but after 24 weeks of therapy, the values were found to return to the same level as those in the control group [61]. However, considering the obtained expression results and the relatively small sample numbers in our study, the lack of significant differences in TLR4 an IL17 in the patients taking ACE and AT1 receptor blockers is not unexpected.

There were several limitations to our study. First, the number of participants was not so large. Second, some of the exclusion criteria, such as chronic inflammatory diseases, were self-reported. If the participants however had some of those diseases, it would have affected our results. Third, it is known that IL17 has relatively short half- life in serum. Although every single blood sample was immediately processed in the laboratory, we could still speculate that the results regarding IL17 might be to some extent underestimated. One more limitation might be the fact that most of the patients were taking multiple antihypertensive therapy. It would had been better if most of the participants were on monotherapy, but generally such hypertensive patients are rare. However, given these limitations, we believe that our study has generated interesting and clinically relevant results.

\section{Conclusions}

In summary, our results indicate that arterial hypertension modulates the immune response, even when blood pressure is considered to be well regulated. The choice of antihypertensive therapy also has an immunomodulatory effects. Our findings are linking 


\section{Kidney \\ Blood Pressure Research}

Simundic et al.: Hypertension and Immunity

TLR4 expression and IL-17A level with diuretics, beta blockers, and the duration of hypertension providing a basis for further studies to better understand the immune-related effects of chronic human hypertension.

\section{Disclosure Statement}

The authors of this manuscript state that they do not have any conflict of interests and nothing to disclose.

\section{References}

1 Panoulas VF, Douglas KM, Milionis HJ, Stavropoulos-Kalinglou A, Nightingale P, Kita MD, Tselios AL, Metsios GS, Elisaf MS, Kitas GD: Prevalence and associations of hypertension and its control in patients with rheumatoid arthritis. Rheumatology (Oxford) 2007;46:1477-1482.

2 Neimann AL, Shin DB, Wang X, Margolis DJ, Troxel AB, Gelfand JM: Prevalence of cardiovascular risk factors in patients with psoriasis. J Am Acad Dermatol 2006;55:829-835.

- 3 Svendsen UG: Evidence for an initial, thymus independent and a chronic, thymus dependent phase of DOCA and salt hypertension in mice. Acta Pathol Microbiol Scand A 1976;84:523-528.

4 Bataillard A, Freiche JC, Vincent M, Sassard J, Touraine JL: Antihypertensive effect of neonatal thymectomy in the genetically hypertensive LH rat. Thymus 1986;8:321-330.

-5 Verlohren S, Muller DN, Luft FC, Dechend R: Immunology in hypertension, preeclampsia, and target-organ damage. Hypertension 2009;54:439-443.

6 Harrison DG, Vinh A, Lob H, Madhur MS: Role of the adaptive immune system in hypertension. Curr Opin Pharmacol 2010;10:203-207.

7 Schiffrin EL: The flame that lights the fire: oxidative stress, inflammation, and renal damage in angiotensin II-induced hypertension. Hypertension 2008;52:205-206.

-8 Schiffrin EL: T lymphocytes: a role in hypertension? Curr Opin Nephrol Hypertens 2010;19:181-186.

-9 Matzinger P: The danger model: a renewed sense of self. Science 2002;296:301-305.

10 Matzinger P: Tolerance, danger, and the extended family. Annu Rev Immunol 1994;12:991-1045.

11 Janeway CA Jr, Medzhitov R: Innate immune recognition. Annu Rev Immunol 2002;20:197-216.

12 Kawai T, Akira S: Toll-like receptor downstream signaling. Arthritis Res Ther 2005;7:12-19.

13 Faure E, Equils O, Sieling PA, Thomas L, Zhang FX, Kirschning CJ, Polentarutti N, Muzio M, Arditi M: Bacterial lipopolysaccharide activates NF-kappaB through toll-like receptor 4 (TLR-4) in cultured human dermal endothelial cells. Differential expression of TLR-4 and TLR-2 in endothelial cells. J Biol Chem 2000;275:11058-11063.

14 Medzhitov R, Preston-Hurlburt P, Janeway CA Jr: A human homologue of the Drosophila Toll protein signals activation of adaptive immunity. Nature 1997;388:394-397.

15 Ji Y, Liu J, Wang Z, Liu N: Angiotensin II induces inflammatory response partly via toll-like receptor 4-dependent signaling pathway in vascular smooth muscle cells. Cell Physiol Biochem 2009;23:265-276.

16 Bomfim GF, Dos Santos RA, Oliveira MA, Giachini FR, Akamine EH, Tostes RC, Fortes ZB, Webb RC, Carvalho MH: Toll-like receptor 4 contributes to blood pressure regulation and vascular contraction in spontaneously hypertensive rats. Clin Sci (Lond) 2012;122:535-543.

-17 Eissler R, Schmaderer C, Rusai K, Kühne L, Sollinger D, Lahmer T, Witzke O, Lutz J, Heemann U, Baumann M: Hypertension augments cardiac Toll-like receptor 4 expression and activity. Hypertens Res 2011;34:551558.

18 Sollinger D, Eißler R, Lorenz S, Strand S, Chmielewski S, Aoqui C, Schmaderer C, Bluyssen H, Zicha J, Witzke O, Scherer E, Lutz J, Heemann U, Baumann M: Damage-associated molecular pattern activated Toll-like receptor 4 signalling modulates blood pressure in L-NAME-induced hypertension. Cardiovasc Res 2014;101:464-472.

19 Hsu SP, Chen CC, Chien CT: Pretreatment of Sialic Acid Efficiently Prevents Lipopolysaccharide-Induced Acute Renal Failure and Suppresses TLR4/gp91-Mediated Apoptotic Signaling. Kidney Blood Press Res 2016;41:267-277. 


\section{Kidney \\ Blood Pressure Research}

20 Yu R, Bo H, Villani V, Spencer PJ, Fu P: The Inhibitory Effect of Rapamycin on Toll Like Receptor 4 and Interleukin 17 in the Early Stage of Rat Diabetic Nephropathy. Kidney Blood Press Res 2016;41:55-69.

-21 Marketou ME, Kontaraki JE, Zacharis EA, Kochiadakis GE, Giaouzaki A, Chlouverakis G, Vardas PE: TLR2 and TLR4 gene expression in peripheral monocytes in nondiabetic hypertensive patients: the effect of intensive blood pressure-lowering. J Clin Hypertens (Greenwich) 2012;14:330-335.

-22 Džumhur A, Zibar L, Wagner J, Simundić T, Dembić Z, Barbić J: Association studies of gene polymorphisms in toll-like receptors 2 and 4 in Croatian patients with acute myocardial infarction. Scand J Immunol 2012;75:517-523.

-23 Harrington LE, Hatton RD, Mangan PR, Turner H, Murphy TL, Murphy KM, Weaver CT: Interleukin 17-producing CD4+ effector T cells develop via a lineage distinct from the Thelper type 1 and 2 lineages. Nat Immunol 2005;6:1123-1132.

24 Madhur MS, Lob HE, McCann LA, Iwakura Y, Blinder Y, Guzik TJ, Harrison DG: Interleukin 17 promotes angiotensin II-induced hypertension and vascular dysfunction. Hypertension 2010;55:500-507.

-25 Michel ML, Keller AC, Paget C, Fujio M, Trottein F, Savage PB, Wong CH, Schneider E, Dy M, Leite-de-Moraes MC: Identification of an IL-17-producing NK1.1(neg) iNKT cell population involved in airway neutrophilia. J Exp Med 2007;204:995-1001.

-26 Coury F, Annels N, Rivollier A, Olsson S, Santoro A, Speziani C, Azocar O, Flacher M, Djebali S, Tebib J, Brytting M, Egeler RM, Rabourdin-Combe C, Henter JI, Arico M, Delprat C: Langerhans cell histiocytosis reveals a new IL-17A-dependent pathway of dendritic cell fusion. Nat Med 2008;14:81-87.

27 Chabaud M, Fossiez F, Taupin JL, Miossec P: Enhancing effect of IL-17 on IL-1-induced IL-6 and leukemia inhibitory factor production by rheumatoid arthritis synoviocytes and its regulation by Th2 cytokines. J Immunol 1998;161:409-414.

28 Krueger GG, Langley RG, Leonardi C, Yeilding N, Guzzo C, Wang Y, Dooley LT, Lebwohl M: A human interleukin-12/23 monoclonal antibody for the treatment of psoriasis. N Engl J Med 2007;356:580-592.

-29 Barczyk A, Pierzchala W, Sozañska E: Interleukin-17 in sputum correlates with airway hyperresponsiveness to methacholine. Respir Med 2003;97:726-733.

-30 Duerr RH, Taylor KD, Brant SR, Rioux JD, Silverberg MS, Daly MJ, Steinhart AH, Abraham C, Regueiro M, Griffiths A, Dassopoulos T, Bitton A, Yang H, Targan S, Datta LW, Kistner EO, Schumm LP, Lee AT, Gregersen PK, Barmada MM, Rotter JI, Nicolae DL, Cho JH: A genome-wide association study identifies IL23R as an inflammatory bowel disease gene. Science 2006;314:1461-1463.

31 Cheng X, Yu X, Ding YJ, Fu QQ, Xie JJ, Tang TT, Yao R, Chen Y, Liao YH: The Th17/Treg imbalance in patients with acute coronary syndrome. Clin Immunol 2008;127:89-97.

32 Nguyen H, Chiasson VL, Chatterjee P, Kopriva SE, Young KJ, Mitchell BM: Interleukin-17 causes Rho-kinasemediated endothelial dysfunction and hypertension. Cardiovasc Res 2013;97:696-704.

-33 Ates I, Ozkayar N, Akyel F, Topcuoglu C, Akyel S, Barça AN, Dede F: The relationship between asymptomatic organ damage, and serum soluble tumor necrosis factor-like weak inducer of apoptosis (sTWEAK) and Interleukin-17A (IL-17A) levels in non-diabetic hypertensive patients. BMC Nephrol 2014;15:159.

-34 Yao W, Sun Y, Wang X, Niu K: Elevated Serum Level of Interleukin 17 in a Population With Prehypertension. J Clin Hypertens (Greenwich) 2015;17:770-774.

-35 Romain M, Taleb S, Dalloz M, Ponnuswamy P, Esposito B, Pérez N, Wang Y, Yoshimura A, Tedgui A, Mallat Z: Overexpression of SOCS3 in T lymphocytes leads to impaired interleukin-17 production and severe aortic aneurysm formation in mice--brief report. Arterioscler Thromb Vasc Biol 2013;33:581-584.

36 Simon T, Taleb S, Danchin N, Laurans L, Rousseau B, Cattan S, Montely JM, Dubourg O, Tedgui A, Kotti S, Mallat Z: Circulating levels of interleukin-17 and cardiovascular outcomes in patients with acute myocardial infarction. Eur Heart J 2013;34:570-577.

-37 Danzaki K, Matsui Y, Ikesue M, Ohta D, Ito K, Kanayama M, Kurotaki D, Morimoto J, Iwakura Y, Yagita H, Tsutsui H, Uede T: Interleukin-17A deficiency accelerates unstable atherosclerotic plaque formation in apolipoprotein E-deficient mice. Arterioscler Thromb Vasc Biol 2012;32:273-280.

38 Abboud FM, Harwani SC, Chapleau MW: Autonomic neural regulation of the immune system: implications for hypertension and cardiovascular disease. Hypertension 2012;59:755-762.

-39 Elenkov IJ, Wilder RL, Chrousos GP, Vizi ES: The sympathetic nerve--an integrative interface between two supersystems: the brain and the immune system. Pharmacol Rev 2000;52:595-638.

-40 Dange RB, Agarwal D, Teruyama R, Francis J: Toll-like receptor 4 inhibition within the paraventricular nucleus attenuates blood pressure and inflammatory response in a genetic model of hypertension. J Neuroinflammation 2015;12:31.

41 Zubcevic J, Waki H, Raizada MK, Paton JF: Autonomic-immune-vascular interaction: an emerging concept 


\section{Kidney \\ Blood Pressure Research}

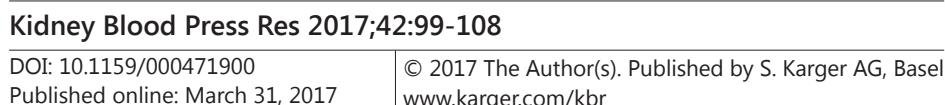

Simundic et al.: Hypertension and Immunity

for neurogenic hypertension. Hypertension 2011;57:1026-1033.

42 Ader R, Felten D, Cohen N: Interactions between the brain and the immune system. Annu Rev Pharmacol Toxicol 1990;30:561-602.

43 Harwani SC, Chapleau MW, Legge KL, Ballas ZK, Abboud FM: Neurohormonal modulation of the innate immune system is proinflammatory in the prehypertensive spontaneously hypertensive rat, a genetic model of essential hypertension. Circ Res 2012;111:1190-1197.

44 Zubcevic J, Waki H, Diez-Freire C, Gampel A, Raizada MK, Paton JF: Chronic blockade of phosphatidylinositol 3-kinase in the nucleus tractus solitarii is prohypertensive in the spontaneously hypertensive rat. Hypertension 2009;53:97-103.

45 Mancia G, Fagard R, Narkiewicz K, Redón J, Zanchetti A, Böhm M, Christiaens T, Cifkova R, De Backer G, Dominiczak A, Galderisi M, Grobbee DE, Jaarsma T, Kirchhof P, Kjeldsen SE, Laurent S, Manolis AJ, Nilsson PM, Ruilope LM, Schmieder RE, Sirnes PA, Sleight P, Viigimaa M, Waeber B, Zannad F: 2013 ESH/ESC Guidelines for the management of arterial hypertension: the Task Force for the management of arterial hypertension of the European Society of Hypertension (ESH) and of the European Society of Cardiology (ESC). J Hypertens 2013;31:1281-1357.

-46 Stumpf C, John S, Jukic J, Yilmaz A, Raaz D, Schmieder RE, Daniel WG, Garlichs CD: Enhanced levels of platelet P-selectin and circulating cytokines in young patients with mild arterial hypertension. J Hypertens 2005;23:995-1000.

-47 Jastrzebski M, Czarnecka D, Rajzer M, Kawecka-Jaszcz K: Increased levels of inflammatory markers in hypertensives with target organ damage. Kardiol Pol 2006;64:802-809; discussion 810-811.

48 Liu N, Liu JT, Ji YY, Lu PP: C-reactive protein triggers inflammatory responses partly via TLR4/IRF3/NFkappaB signaling pathway in rat vascular smooth muscle cells. Life Sci 2010;87:367-374.

49 Ha T, Li Y, Hua F, Ma J, Gao X, Kelley J, Zhao A, Haddad GE, Williams DL, William Browder I, Kao RL, Li C: Reduced cardiac hypertrophy in toll-like receptor 4-deficient mice following pressure overload. Cardiovasc Res 2005;68:224-234.

50 Kao CY, Huang F, Chen Y, Thai P, Wachi S, Kim C, Tam L, Wu R: Up-regulation of CC chemokine ligand 20 expression in human airway epithelium by IL-17 through a JAK-independent but MEK/NF-kappaBdependent signaling pathway. J Immunol 2005;175:6676-6685.

51 Hartupee J, Liu C, Novotny M, Li X, Hamilton T: IL-17 enhances chemokine gene expression through mRNA stabilization. J Immunol 2007;179:4135-4141.

-52 Krebs CF, Lange S, Niemann G, Rosendahl A, Lehners A, Meyer-Schwesinger C, Stahl RA, Benndorf RA, Velden J, Paust HJ, Panzer U, Ehmke H, Wenzel UO: Deficiency of the interleukin 17/23 axis accelerates renal injury in mice with deoxycorticosterone acetate+angiotensin ii-induced hypertension. Hypertension 2014;63:565-571.

53 Farmer P, Pugin J: Beta-adrenergic agonists exert their "anti-inflammatory" effects in monocytic cells through the IkappaB/NF-kappaB pathway. Am J Physiol Lung Cell Mol Physiol 2000;279:L675-L682.

54 Grisanti LA, Evanson J, Marchus E, Jorissen H, Woster AP, DeKrey W, Sauter ER, Combs CK, Porter JE: Proinflammatory responses in human monocytes are beta1-adrenergic receptor subtype dependent. Mol Immunol 2010;47:1244-1254.

55 Palmas W, Ma S, Psaty B, Goff DC Jr, Darwin C, Barr RG: Antihypertensive medications and C-reactive protein in the multi-ethnic study of atherosclerosis. Am J Hypertens 2007;20:233-241.

56 Ganta CK, Lu N, Helwig BG, Blecha F, Ganta RR, Zheng L, Ross CR, Musch TI, Fels RJ, Kenney MJ: Central angiotensin II-enhanced splenic cytokine gene expression is mediated by the sympathetic nervous system. Am J Physiol Heart Circ Physiol 2005;289:H1683-H1691.

57 Nash DT: Rationale for combination therapy in hypertension management: focus on angiotensin receptor blockers and thiazide diuretics. South Med J 2007;100:386-392.

-58 Zhao H, Li M, Wang L, Su Y, Fang H, Lin J, Mohabeer N, Li D: Angiotensin II induces TSLP via an AT1 receptor/NF-KappaB pathway, promoting Th17 differentiation. Cell Physiol Biochem 2012;30:1383-1397.

59 Schieffer B, Bünte C, Witte J, Hoeper K, Böger RH, Schwedhelm E, Drexler H: Comparative effects of AT1antagonism and angiotensin-converting enzyme inhibition on markers of inflammation and platelet aggregation in patients with coronary artery disease. J Am Coll Cardiol 2004;44:362-368.

-60 Ridker PM, Danielson E, Rifai N, Glynn RJ: Valsartan, blood pressure reduction, and C-reactive protein: primary report of the Val-MARC trial. Hypertension 2006;48:73-79.

61 Navalkar S, Parthasarathy S, Santanam N, Khan BV: Irbesartan, an angiotensin type 1 receptor inhibitor, regulates markers of inflammation in patients with premature atherosclerosis. J Am Coll Cardiol 2001;37:440-444. 